\title{
History of Japan's chart production in 150 years
}

\author{
KAJIMURA Toru
}

Hydrographic \& Oceanographic Department, Japan Coast Guard

Keywords: Navigational chart, History

\begin{abstract}
:
In 1853, the United States sent Commodore Perry with 4 warships to Japan, and urged opening the country to the world. Since then, Japan had entered into treaties of commerce with Western nations, and opened the ports for these nations. However, Japan was in military disadvantage with other nations having charting knowledge of Japan and it surroundings. As a result, a decision was made to establish chart production capabilities in Japan in the view of the national security. Soon after, the Japanese chief military commander opened two naval officer training facilities in Nagasaki (1855) and Tsukiji (1857). Surveying was also one of the subjects of taught at these training organizations.
\end{abstract}

Japan Hydrographic Department (JHD, currently Japan Hydrographic \& Oceanographic Department) was established as the organization for chart production under the navy in 1871, and graduates of the above naval officer training facilities led the activities of JHD in its early stage. The first Chief Hydrographer YANAGI Narayoshi was one of them. JHD published its first navigational chart "KAMAISHI BAY of RIKUCHU" in 1872, the next year of its establishment, and expanded its chart series after that.

As Japan experienced several wars and expanded its national jurisdiction by 1945, JHD expanded its chart series. Most of these charts were open to the merchant ships, but some of them were not open to public as military secrets at that time. Furthermore, JHD, as one of the organizations under the navy, made aeronautical charts for naval airplanes. These charts have been stored in archives, but some were lost in fires. Not all of charts ever published by JHD exist now. The existing charts published by 1945 are kept in the Hydrographic \& Oceanographic Museum.

After World War II, JHD was restructured as one of the organizations of Japan Coast Guard under the Ministry of Transport (currently the Ministry of Land, Infrastructure and Transport). The chart production of Japan in post war days has received big influences by the economic situation of Japan and the world, frameworks of international societies and developments of the technologies.

In the viewpoint of the economic situation, the number of chart publication increased due to the large number of the constructions of domestic harbours in the periods of the post war reconstruction and the following high economic growth of Japan, but it has decreased little by little since 1970's by the influences of such as depressions of domestic economy, and decrease of ships registered in Japan and Japanese mariners. On the other hand, JHOD has published navigational charts written only in English in recent years for foreign mariners which number increases like supplementing a decrease of Japanese mariners. Moreover, JHOD has published basic maps of the sea as basic material of use, development, environmental preservation and the natural disaster prevention etc. of the ocean.

In the viewpoint of the frameworks of the international societies, JHOD has published fishery charts which show the fishery areas on the agreements between neighbouring countries, and also writes the straight baselines and limits of the territorial sea on the navigational charts according to United Nations Convention on the Law of the Sea.

In the viewpoint of the developments of the technologies, innovations of positioning technology and improvement of the computer ability influenced largely in chart production. JHOD used to publish Decca charts and Loran charts in the age of radio navigation. Because satellite navigation became common in recent years, the difference between WGS84 and Tokyo-datum (nearly 500m) was put in questions. Corresponding to it, JHOD temporarily published some Tokyo-datum charts on which latitude and longitude lines based on WGS84 in green were added, and since 2000, JHOD has published navigational charts based on WGS84 and no more on Tokyo-datum. Furthermore, with the growth of computer ability, JHOD has shifted its chart compilation from full manually to by using computer assisted partly, and in 1996, JHOD established chart compilation process under fully computer assisted. In addition, JHOD published the first electronic navigational chart (ENC) in the world in 1995.

JHOD as the responsible organization of Japan for chart production will continue to produce charts in the future adjusting to the environment that surrounds charts and navigations. 